\title{
Storage stability of snacks with reduced saturated and trans fatty acids contents
}

\author{
Estabilidade de snacks com teores reduzidos de ácidos graxos saturados e trans durante o armazenamento
}

\author{
Vanessa Dias CAPRILES ${ }^{1}$, Rosana Aparecida Manólio SOARES ${ }^{1}$, José Alfredo Gomes ARÊAS ${ }^{1 *}$
}

\begin{abstract}
Resumo
A gordura vegetal parcialmente hidrogenada tem sido utilizada na aromatização de snacks. Entretanto, o risco à saúde ocasionado pelo elevado consumo de ácidos graxos saturados e trans (AGT) vem estimulando o desenvolvimento de abordagens alternativas a essa gordura. Substituímos a gordura vegetal parcialmente hidrogenada (F) por óleo de canola $(\mathrm{O})$ na aromatização de snacks. Snacks com diferentes níveis de $\mathrm{O}$ foram produzidos, embalados e armazenados em temperatura ambiente durante vinte semanas. Monitoramos o perfil de ácidos graxos, o teor de substâncias reativas ao TBA (TBARS), a força de cisalhamento e a aceitabilidade sensorial. A substituição total reduziu o teor de ácidos graxos saturados em 72,5\%, em comparação aos snacks comerciais. Os snacks eram inicialmente isentos de AGT, porém, após 8 semanas, esses compostos surgiram, havendo aumento gradual durante o período de armazenamento. Entretanto, estes níveis mantiveram-se inferiores aos observados em snacks comercializados. Também foram observados baixos teores de TBARS e estabilidade da força de cisalhamento. Snacks aromatizados com F ou O foram igualmente bem aceitos durante as vinte semanas de armazenamento. É possível desenvolver snacks com teores reduzidos de ácidos graxos saturados e trans, estáveis durante o armazenamento, mantendo a elevada aceitabilidade sensorial típica deste tipo de produto.
\end{abstract}

Palavras-chave: snacks extrusados; ácidos graxos trans; ácidos graxos saturados; aceitabilidade sensorial; vida de prateleira.

\begin{abstract}
Partially hydrogenated vegetable oil has been used in snack flavoring for its ability to entrap hydrophobic aroma compounds. However, increasing concerns about the health risks of saturated and trans fatty acids (TFA) consumption led to the development of alternative agents for this use. We studied the use of rapeseed oil $(\mathrm{O})$ as a replacement for partially hydrogenated vegetable oil (F) in snack flavoring. Products with several different rapeseed oil contents were designed, packed, and then stored for twenty weeks at room temperature. Fatty acids compositions, TBA reactive substances (TBARS), shear strength and sensory acceptability were assessed throughout storage time. Total replacement reduced saturated fat by $72.5 \%$ in relation to market available snacks. TFA were initially absent in these products, but their production occurred spontaneously on the $8^{\text {th }}$ week with gradual increase during storage up to levels still lower than those observed in commercially available snacks. Low TBARS levels and stability of shear strength during the twenty-week of storage were also observed. Snacks flavored with $\mathrm{F}$ or O were equally well accepted during the storage period. It is feasible to develop a storage stable snack with reduced saturated and trans fatty acid contents while maintaining the high sensory acceptability typical of this food product.

Keywords: extruded snacks; trans fatty acids; saturated fatty acids; sensory assessment; shelf life.
\end{abstract}

\section{Introduction}

The production and consumption of expanded ready-toeat products through extrusion cooking has notably increased worldwide. This processing technology is widely used to restructure starch and protein-based materials thus allowing the manufacturing of a variety of textured convenience foods. Extrusion cooking is a high-temperature short-time (HTST) processing technology in which raw materials are exposed to a combination of moisture, pressure, temperature, and mechanical shear resulting in stable products that have become very popular as convenience foods. Among these, snacks are the main products manufactured by extrusion (ARÊAS, 1992; MITCHELL; ARÊAS, 1992; MERCIER; LINKO; HARPER, 1998).

The necessary application of flavor after extrusion requires fat or oil addition onto the surface of extrudates to entrap the added flavors, which are usually hydrophobic (YULIANI et al., 2006). Snacks are commonly flavored with more than $20 \%$ partially hydrogenated vegetable oil, which increase their acceptability. This method of flavoring gives rise to the main nutritional disadvantage of snacks because these fats contain high amounts of saturated (SAFA) and trans fatty acids (TFA). Snacks marketed in several countries contain 25.5-39.0\% of total fat with fatty acid profiles yielding $13.6-50.0 \%$ of SAFA and $0.7-30.4 \%$ of TFA (ENIG et al., 1983; ARO et al., 1998; TAVELLA et al., 2000; ROBINSON; SINGH; KAYS, 2008).

Health concerns about the increasing consumption of partially hydrogenated vegetable oil have grown in the past years. Studies show that a high intake of SAFA contributes to the development of coronary heart disease. A high intake of TFA has more severe effects than does the consumption of SAFA;

Recebido para publicação em 23/6/2008

Aceito para publicação em 12/11/2008 (003592)

Departamento de Nutrição da Faculdade de Saúde Pública, Universidade de São Paulo - USP, Av. Dr. Arnaldo, 715, CEP 01246-904, São Paulo - SP, Brasil,

E-mail: jagareas@usp.br

${ }^{*}$ A quem a correspondência deve ser enviada 
thereby increasing LDL-cholesterol levels and simultaneously decreasing HDL-cholesterol levels, and increasing the risk of cancer (JUDD et al., 1994; CHAIR et al., 1996; ASCHERIO; WILLETT, 1997; SUBBAIAH; SUBRAMANIAN; LIU, 1998; ALLISON et al., 1999; SCHAEFER, 2002).

The public health problems caused by the high consumption of SAFA and TFA may be diminished by reducing their contents in one of their main sources, ready-to-eat convenience products without impairing their acceptability. In a previous study (CAPRILES; AREAAS, 2005), the SAFA and TFA contents of snacks were reduced by replacing the partially hydrogenated vegetable oil by rapeseed oil. The aim of this study was to investigate storage stability of these snacks with reduced saturated and trans fatty acids contents.

\section{Materials and methods}

\subsection{Preparation of snacks samples}

Snacks were produced in a single-screw extruder (L/D ratio 20) consisting of three independent zones of controlled temperature in the barrel with a production capacity of $180 \mathrm{~kg}$ per hour (Inbra 200 - INBRAMAQ, Indústria de Máquinas Ltda, São Paulo, Brazil). Germ-free maize flour (Zea mays L.) with moisture adjusted to $16 \%$ was used. The following conditions were set on the basis of preliminary experiments: $398 \mathrm{rpm}$ screw rotation, 1:1 screw compression ratio. The temperature profiles were kept constant in the feed and compression metering zones at $25^{\circ} \mathrm{C}$ and in the die at $90^{\circ} \mathrm{C}$. The extruded products were cut with a knife cutter as they left the extruder die. Snacks yielded cylindrical shapes with a radial expansion ratio of 4.6. The radial expansion ratio was the ratio between the cross-sectional area of the dried extrudate (obtained by a caliper rule) and the crosssectional area of the extruder die. The values reported are the average of 30 measurements.

Flavoring was performed in a coating pan (AIR $400-$ Erweka, Heusenstamm, Germany) by aspersion of half the amount of fat followed by sprinkling of the dry ingredients and a second aspersion of the remaining fat. All the samples were flavored with a mixture of $1.5 \%$ of salt, $0.4 \%$ of monosodium glutamate, $0.02 \%$ of disodium glutamate and $4 \%$ of powdered cheese flavor (Raí Ingredients Comercial Ltda., São Paulo, Brazil) differing only in fat composition.

Five snacks were developed with a total of $22 \%$ of lipids. These samples were flavored with the replacement of $0,25,50$, 75 , and $100 \%$ partially hydrogenated vegetable fat by rapeseed oil. Additionally, three snacks were flavored only with rapeseed oil (100\% replacement) with a gradual reduction of total lipids contents $(17,12$, and $10 \%$ total lipids) according to Capriles and Arêas (2005). As a whole, eight different snack samples were analyzed.

Snacks were packed in flexible metallic/plastic bags $\left(17 \mathrm{~g} / \mathrm{m}^{2}\right.$ polyester, $22 \mathrm{~g} / \mathrm{m}^{2}$ aluminum and $80 \mathrm{~g} / \mathrm{m}^{2}$ polyethylene) provided by Rangel Indústria e Comércio Ltda (Brazil). The packs were filled with $30 \mathrm{~g}$ snacks and were heat sealed with a Selovac Model 200-B machine (Selovac S.A., Brazil). The samples were stored at room temperature $\left(20-25^{\circ} \mathrm{C}\right)$ for twenty weeks. Six random packages of each sample were opened monthly; the contents were mixed and fifteen random snacks were kept for texture measurement. The remaining snacks were ground and used for the rest of the analyses. Eight random packages of the sample flavored with $22 \%$ of partially hydrogenated vegetable oil and of the sample flavored with $22 \%$ of rapeseed oil were opened for sensory evaluation.

\subsection{Fatty acid composition}

Ten grams of milled snacks were used for the fatty acid composition analysis. The same procedure that is used for snacks available in the market was adopted for our lab-developed products. An extract aliquot containing $50 \mathrm{mg}$ of lipids, obtained by a dry column method in accordance to Marmer and Maxwell (1981), was collected, and then esterification of the lipid fraction was performed using Hartman and Lago (1973) method. All reagents were p.a. quality purchased from Merck (Brazil). Fatty acid methyl esters were diluted to about $1 \%$ with hexane, and $1 \mu \mathrm{L}$ of this solution was injected into a gas chromatograph (Chrompack CP9002) equipped with a fused silica capillary column, CP-Sil $88(50 \mathrm{~m} \times 0.25 \mathrm{~mm}$ and $0.2 \mu \mathrm{m}$ id). Hydrogen was the carrier gas (flow $1.5 \mathrm{~mL} . \mathrm{min}^{-1}$ ) with split injection of $1: 70$. The injector temperature was set at $270{ }^{\circ} \mathrm{C}$. The oven temperature profile was: $100{ }^{\circ} \mathrm{C}$ for 2 minutes then increased at the rate of $5{ }^{\circ} \mathrm{C} . \mathrm{min}^{-1}$ (for 28 minutes) to the final temperature of $240^{\circ} \mathrm{C}$. The flame ionization detector temperature was set at $300^{\circ} \mathrm{C}$.

Fatty acid methyl esters were identified by comparing the retention times with those of Sigma Aldrich 189-19 standard (Fatty acid methyl ester mixture). The cis/trans linoleic and linolenic fatty acid isomers were identified by comparison with standards according to the AOCS (1997a) Ch 2a-94 Recommended Practice and the AOCS (1997b) Ce 1f-96 Official Method. The standards used were Sigma Aldrich L8404 (Linoleic acid methyl ester cis/trans isomers) and L6034 (Linolenic acid methyl ester, isomer mix). The amount of each component was calculated by an area normalization method. The fatty acid profile was expressed in \% of total lipids.

SAFA and TFA data were also converted to $g$ fatty acid per $100 \mathrm{~g}$ of snack. Lipid conversion factors were obtained according to Weihrauch et al. (1977).

\subsection{Lipid oxidation analysis}

Lipid oxidation was measured in triplicate by the 2-thiobarbituric acid (TBA) method according to Vynce (1970). Five grams of milled snacks were mixed with $40 \mathrm{~mL}$ trichloroacetic acid (7.5\%) using an Ultra-Turrax mixer (TE 102 - Marconi, Brazil). The samples were centrifuged at $1500 \mathrm{~g}$ for 20 minutes; the supernatants were filtered through quantitative filter paper (Whatman n. 41). Five milliliters of the filtrate were mixed with $5 \mathrm{~mL}$ thiobarbituric acid $\left(20 \mathrm{mmol.L} \mathrm{L}^{-1}\right)$. The tube contents were homogenized and incubated at $97^{\circ} \mathrm{C}$ for 40 minutes. Absorbance was measured at $538 \mathrm{~nm}$. The values reported were averages of three measurements, and the results were expressed as mg of TBARS (thiobarbituric acid-reactive substances) $\mathrm{kg}^{-1}$ of snack samples. 


\subsection{Textural measurement}

The shear strength was chosen to represent the textural properties of snacks. It corresponded to the maximum force offered by the sample submitted to shear in a Stable Micro System TA-XT2i Texture Analyzer (Stable Micro System, U.K.) equipped with a Warner-Bratzler device. The cross-head speed was $1 \mathrm{~mm} \cdot \mathrm{s}^{-1}$. Fifteen randomly collected samples of each snack were analyzed.

\subsection{Sensory acceptability}

Ethical approval for this procedure was obtained from the human experimentation committee of the School of Public Health, University of São Paulo, São Paulo, Brazil. The sensory evaluation of snacks flavored with $22 \%$ of partially hydrogenated vegetable oil (F) and with $22 \%$ of rapeseed oil (O) was carried out with the purpose of comparing their acceptability during storage. Fifty snack consumers (untrained panelists), recruited among the staff and students of the School of Public Health, tested both snacks without prior knowledge of the product composition. They were instructed to eat snacks and rinse their mouth with water between samples to minimize any residual effects. Three units of each sample were served in a polythene pack that was blind-coded with three random numbers. Each panelist evaluated the snacks' overall acceptability on a ninepoint hedonic scale, which varied from 1 (dislike extremely) to 9 (like extremely) (STONE; SIDEL, 1985).

\subsection{Statistical analysis}

The data were subjected to one-way analysis of variance (ANOVA). Differences among the mean values of the various snacks and storage periods were determined by the Tukey test. The Student's t test was performed to compare the means of sensory acceptability in the same storage period. Statistical analyses were performed using the SPSS software (SPSS Institute Inc., Cary, NC, USA) and the significance was defined at $\mathrm{p}<0.05$.

\section{Results and discussion}

Fatty acid profiles of the lab-developed products were compared with those of market available snacks (Table 1). Samples of eleven products were acquired in supermarkets in São Paulo, Brazil. The majority of these products contained about $20 \%$ lipids. Their fatty acid profile yielded, in average, $33.5 \pm 15.9 \%$ of saturated fatty acids (SAFA), $2.2 \pm 1.6 \%$ of trans fatty acids (TFA), $30.4 \pm 22.1 \%$ of monounsaturated fatty acids (MUFA) and $32.8 \pm 8.2 \%$ of polyunsaturated fatty acids (PUFA). SAFA levels varied widely, from $13.2 \%$ to as high as $49.8 \%$ in some products; while TFA contents varied from 0.5 to $5.6 \%$. Our results are in agreement with the findings of other researchers. Enig et al. (1983) found 13.6-31.8\% of SAFA and 13.4-30.4\% of TFA in fatty acid profiles of market available snacks in the United States of America. Aro et al. (1998) reported 35-46\% of SAFA and $0.7-1.0 \%$ of TFA in fatty acid profiles of commercial snacks in Europe while Tavella et al. (2000) found 50\% of SAFA and $10.6 \%$ of TFA in fatty acid profiles of snacks in Argentina.
The effect of the partial replacement of partially hydrogenated oil by rapeseed oil on fatty acid profile of snacks is also shown in Table 1 . The snack flavored with $22 \%$ of partially hydrogenated vegetable oil $(22 \% \mathrm{~F})$, used as a control in this work, presented $27.6 \%$ of SAFA and $5.0 \%$ of TFA. The progressive replacement with rapeseed oil caused proportional reduction of SAFA and TFA. Total replacement yields a snack completely free of TFA and with merely $9.2 \%$ of SAFA content. Snacks flavored with $22 \%$ of rapeseed oil $(22 \% \mathrm{O})$ resulted in $66.7 \%$ less SAFA than snack $22 \% \mathrm{~F}$; and $72.5 \%$ less than the mean value found in market available snacks.

Palmitic acid (C16:0) was the SAFA found in the highest amounts in lab-developed and commercial snacks along with oleic (C18:1 9c) and linoleic (C18:2 9c12c) acids, MUFA and PUFA, respectively. Elaidic acid (C18:1t) was the TFA found in the highest amounts (Table 1). Similar results were observed by Chiara, Sichieri and Carvalho (2003) and Martin et al. (2005) in the evaluation of some commercial Brazilian foods containing partially hydrogenated vegetable oil.

No changes in the instauration degree of snacks fatty acids profile were observed during the storage period. However, differences in the levels of cis/trans isomers of oleic, linoleic, and linolenic fatty acid levels were observed.

Figure 1a shows that the progressive replacement with rapeseed oil caused proportional reduction of TFA in all snacks flavored with mixtures of fat and oil over time. The appearance of TFA in the snack flavored with $22 \%$ O was first noticed after 8 weeks of storage. The same increase was observed in the snack flavored with $5 \% \mathrm{~F}+17 \% \mathrm{O}$.

Samples flavored with the replacement of 50-100\% partially hydrogenated vegetable oil by rapeseed oil presented a TFA reduction of at least $40 \%$ during the 20 weeks of storage. Despite its appearance, the snack flavored with $22 \%$ O presented about one-third of TFA levels compared to the snack flavored with $22 \% \mathrm{~F}$. The TFA values found in the products showed in Figure 1a fell within the range observed in commercial snacks

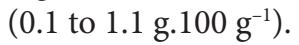

During storage, all samples flavored with rapeseed oil showed an increase of TFA after 8 weeks of storage. These contents increased to about $0.5 \mathrm{~g} .100 \mathrm{~g}^{-1}$ Figure $1 \mathrm{~b}$. TFA were formed in snacks flavored with rapeseed oil Figure $1 \mathrm{~b}$ but in lower amounts than in snacks flavored with mixture of partially hydrogenated oil and rapeseed oil Figure 1a throughout the whole storage time. Snacks flavored with 12 or $10 \%$ O presented only about $50 \%$ of TFA amounts when compared to snacks flavored with $22 \% \mathrm{O}$ and about $17 \%$ when compared to snacks flavored with $22 \% \mathrm{~F}$ during storage.

An increase in trans isomers is related to the first step of lipid peroxidation, which is initiated by a homogeneous split of a C-H bond adjacent to cis double bonds in unsaturated fatty acids. The reaction progress is favored by the formation of more stable forms of allylic radicals in which the unpaired electrons are distributed over several carbon atoms. Due to resonance stabilization, these radicals typically shift the double bonds resulting in cis/trans isomerization that leads to the formation 
Table 1. Fatty acid profiles, including trans fatty acid contents, of snacks flavored with blends of partially hydrogenated oil and rapeseed oil and market available products.

\begin{tabular}{|c|c|c|c|c|c|c|c|c|c|}
\hline \multirow[t]{2}{*}{ Fatty acids (\%) } & \multicolumn{9}{|c|}{ Snacks } \\
\hline & $22 \% \mathrm{~F}$ & $17 \% \mathrm{~F}+5 \% \mathrm{O}$ & $11 \% \mathrm{~F}+11 \% \mathrm{O}$ & $5 \% \mathrm{~F}+17 \% \mathrm{O}$ & $22 \% \mathrm{O}$ & $17 \% \mathrm{O}$ & $12 \% \mathrm{O}$ & $10 \% \mathrm{O}$ & Market \\
\hline$\sum$ Saturated & 27.6 & 24.3 & 20.1 & 21.8 & 9.2 & 9.2 & 9.0 & 9.9 & 33.5 \\
\hline $\mathrm{C} 4: 0$ & 0.7 & 0.8 & 0.9 & 0.9 & 1.0 & 0.7 & 0.6 & 1.4 & 0.6 \\
\hline C12:0 & 0.1 & 0.1 & 0.1 & 0.0 & 0.0 & 0.0 & 0.0 & 0.0 & 0.1 \\
\hline C14:0 & 0.8 & 0.6 & 0.5 & 0.3 & 0.0 & 0.0 & 0.1 & 0.1 & 0.4 \\
\hline $\mathrm{C} 22: 0$ & 0.1 & 0.2 & 0.2 & 0.3 & 0.3 & 0.3 & 0.3 & 0.3 & 0.3 \\
\hline C24:0 & 0.0 & 0.0 & 0.0 & 0.0 & 0.0 & 0.0 & 0.0 & 0.0 & 0.4 \\
\hline$\sum$ Monounsaturated & 17.7 & 26.2 & 35.0 & 41.1 & 58.2 & 58.4 & 59.0 & 58.2 & 32.8 \\
\hline $\mathrm{C} 16: 1$ & 0.4 & 0.4 & 0.3 & 0.3 & 0.2 & 0.2 & 0.2 & 0.2 & 0.1 \\
\hline $\mathrm{C} 18: 19 \mathrm{c}$ & 17.3 & 25.8 & 34.7 & 40.8 & 58.0 & 58.2 & 58.8 & 58.0 & 32.7 \\
\hline$\sum$ Trans & 5.0 & 4.0 & 2.9 & 1.5 & 0.0 & 0.0 & 0.0 & 0.0 & 2.2 \\
\hline $\mathrm{C} 18: 19 \mathrm{t}$ & 3.68 & 2.95 & 1.99 & 1.15 & 0.0 & 0.0 & 0.0 & 0.0 & 1.15 \\
\hline $\mathrm{C} 18: 29 \mathrm{t} 12 \mathrm{t}$ & 0.21 & 0.0 & 0.09 & 0.0 & 0.0 & 0.0 & 0.0 & 0.0 & 0.03 \\
\hline $\mathrm{C} 18: 29 \mathrm{c} 12 \mathrm{t}$ & 0.49 & 0.4 & 0.35 & 0.23 & 0.0 & 0.0 & 0.0 & 0.0 & 0.03 \\
\hline $\mathrm{C} 18: 29 \mathrm{t} 12 \mathrm{c}$ & 0.4 & 0.4 & 0.28 & 0.0 & 0.0 & 0.0 & 0.0 & 0.0 & 0.03 \\
\hline $\mathrm{C} 18: 39 \mathrm{t} 12 \mathrm{c} 15 \mathrm{t}$ & 0.25 & 0.29 & 0.21 & 0.13 & 0.0 & 0.0 & 0.0 & 0.0 & 0.04 \\
\hline $\mathrm{C} 18: 39 \mathrm{c} 12 \mathrm{c} 15 \mathrm{t}$ & 0.0 & 0.0 & 0.0 & 0.0 & 0.0 & 0.0 & 0.0 & 0.0 & 0.56 \\
\hline $\mathrm{C} 18: 39 \mathrm{c} 12 \mathrm{t} 15 \mathrm{c} / 9 \mathrm{t} 12 \mathrm{c} 15 \mathrm{c}$ & 0.0 & 0.0 & 0.0 & 0.0 & 0.0 & 0.0 & 0.0 & 0.0 & 0.34 \\
\hline
\end{tabular}

$\mathrm{F}=$ partially hydrogenated oil; $\mathrm{O}=$ rapeseed oil; athe values reported were averages of eleven market available snacks flavored with hydrogenated vegetable fat. Market available snacks samples were acquired in supermarkets in São Paulo, 2003.
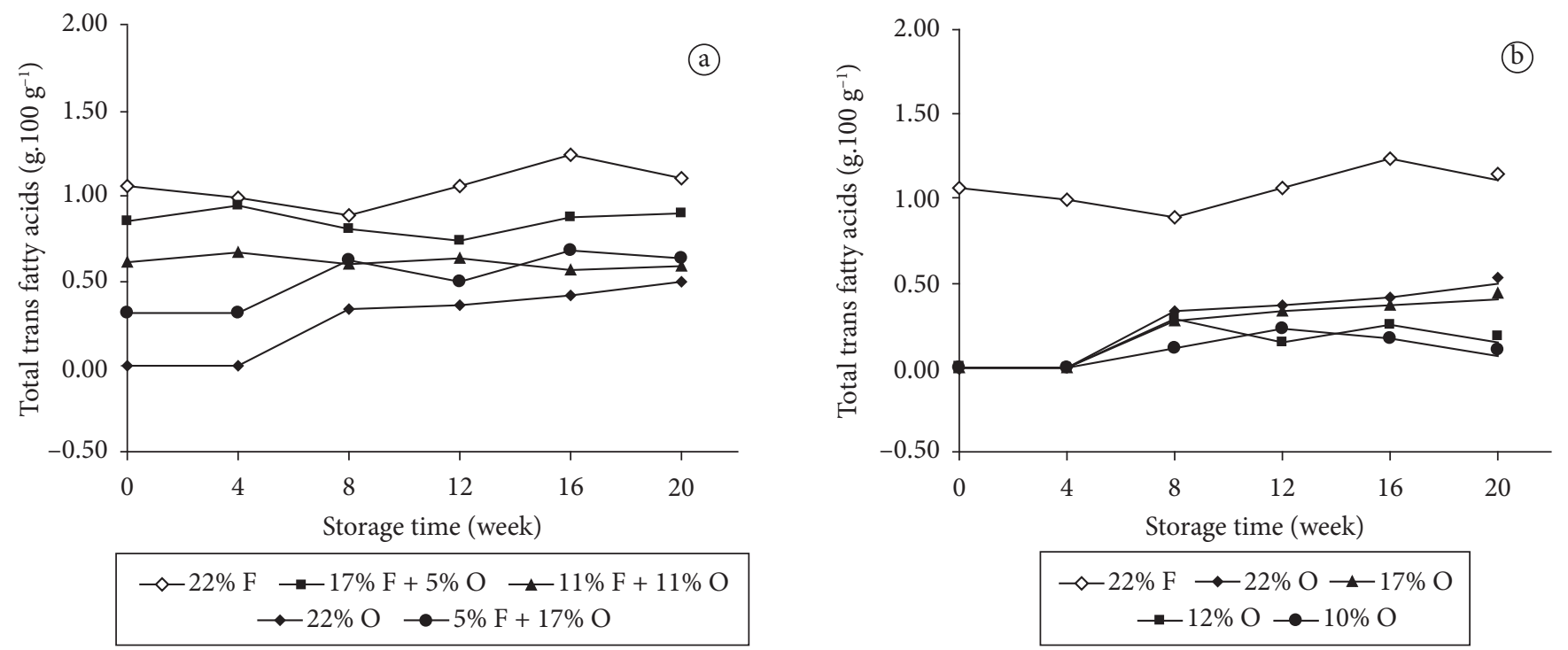

Figure 1. Changes in total trans fatty acids contents in snacks flavored with a) mixes of partially hydrogenated oil and rapeseed oil up to $22 \%$ $(\mathrm{F})$; and b) snacks flavored only with rapeseed oil $(\mathrm{O})$ during twenty weeks of storage.

of trans fatty acids. (FRANKEL, 1984; HSIEH; KINSELA, 1989; NAWAR, 1996).

The TBA value is an index of lipid oxidation measuring malonaldehyde (MDA) content. MDA formed through hydroperoxides, which is the initial reaction product of lipid oxidation. No significant differences in TBARS concentration among samples were observed during the storage period. TBARS values increased for each of the samples until the $16^{\text {th }}$ 
week (Figure 2). Throughout storage, TBARS values ranged from 0.02 to $0.08 \mathrm{mg} / \mathrm{kg}$, values below the usual threshold concentration of $0.60 \mathrm{mg} / \mathrm{kg}$ detected by panelists according to Greene and Cumuze (1981). The low TBARS values and the absence of off-flavors indicate that the lipid oxidation did not progress significantly during the studied period. However, although the lipid peroxidation was in its first stages, free radical formation resulted in the appearance of trans fatty acids.

There is no scientific basis to establish a daily value for TFA consumption. Considering that a high intake of TFA is associated with an increased risk of coronary heart diseases, a maximal daily intake reduction of TFA is required to minimize health risks. To achieve this at the individual level, legislation in some countries, including Brazil, has limited TFA in foods to a maximum of $0.2 \mathrm{~g}$ TFA/portion for a trans-free claim on the label (BRAZIL, 2003).

However, it was observed that commercial snacks in Brazil contain up to $0.3 \mathrm{~g}$ TFA/portion $(30 \mathrm{~g})$. We found similar results for snacks flavored with $22 \% \mathrm{~F}$ in our study. Despite the formation of TFA during storage, the total replacement with rapeseed oil $(22 \% \mathrm{O})$ produced only half of this quantity during a 20 -week storage $(0.15 \mathrm{~g}$ TFA/portion) while gradual reduction of total lipids contents to 12 and $10 \%$ generate snacks containing up to $0.10 \mathrm{~g}$ TFA/portion during storage. This allows the claim of a TFA-free product during all storage time.

The maximum strength to completely shear the snack, which is an important predicting factor of the sensory acceptance of the product, was evaluated during the twenty weeks of storage. No differences were detected in shear strength values during the shelf life of all snacks samples (mean values of 53,4 N).

There was no significant difference between the sensory acceptability of snacks flavored with $22 \% \mathrm{~F}$ and $22 \% \mathrm{O}$ indicating that these samples were equally well accepted by consumers during the 20 weeks of storage (Table 2). Muñoz, Civille and
Carr (1992) considered an acceptability score of 6 in a 9-point hedonic scale as a commercial or quality limit. By using this acceptability score, both snack types were acceptable and had a good commercial potential. Eighty to ninety eight percent of the judges assigned overall acceptability scores equal or higher than six for both snacks during the storage lifetime.

To reduce the risk of cardiovascular disease, consumers need to adopt a healthier low-cholesterol diet with minimal SAFA and TFA ingestion. Food industries must decrease or exclude these substances from their products in order to address the present health concern. Approaches similar to ours can be used by food industries contributing to reduce SAFA and TFA consumption. However, as observed in this study, the major constraint of partially hydrogenated vegetable oil replacement in the snacks flavoring process is the reduction of shelf life of the final product due to the natural appearance of TFA through lipid peroxidation. Other methods, such as fat-free snack production, should be investigated. Extrusion of corn grits with previously added flavoring compounds (YULIANI et al.,

Table 2. Effect of storage time on overall acceptability of snacks flavored with partially hydrogenated oil and rapeseed oil.

\begin{tabular}{cccccc}
\hline \multirow{2}{*}{$\begin{array}{c}\text { Storage } \\
\text { time } \\
\text { (week) }\end{array}$} & $\mathrm{n}$ & \multicolumn{2}{c}{ Snack 22\%O } & \multicolumn{2}{c}{ Snack 22\%F } \\
\cline { 3 - 6 } & & Mean & Scores $\geq 6$ & Mean & Scores $\geq 6$ \\
0 & 50 & $6.88^{\mathrm{a} ; \mathrm{v}} \pm 1.42$ & $90 \%$ & $7.50^{\mathrm{a}, \mathrm{v}} \pm 1.19$ & $98 \%$ \\
4 & 49 & $6.80^{\mathrm{a} ; \mathrm{v}} \pm 1.45$ & $88 \%$ & $6.83^{\mathrm{a}, \mathrm{vx}} \pm 1.37$ & $88 \%$ \\
8 & 50 & $6.64^{\mathrm{a} ; \mathrm{v}} \pm 1.39$ & $82 \%$ & $6.60^{\mathrm{a} ; \mathrm{x}} \pm 1.52$ & $84 \%$ \\
12 & 50 & $6.80^{\mathrm{a} ; \mathrm{v}} \pm 1.14$ & $92 \%$ & $7.30^{\mathrm{a}, \mathrm{vx}} \pm 1.13$ & $96 \%$ \\
16 & 50 & $6.74^{\mathrm{b} ; \mathrm{v}} \pm 1.19$ & $90 \%$ & $7.46^{\mathrm{a}, \mathrm{vx}} \pm 1.15$ & $94 \%$ \\
20 & 47 & $6.34^{\mathrm{a}, \mathrm{v}} \pm 1.55$ & $81 \%$ & $6.83^{\mathrm{a}, \mathrm{vx}} \pm 1.35$ & $89 \%$ \\
\hline
\end{tabular}

$\mathrm{F}=$ partially hydrogenated oil; $\mathrm{O}=$ rapeseed oil; abmeans $\pm \mathrm{SD}$, in the same row, followed by different superscripts, are significantly different $(\mathrm{p}<0.05)$; vx means $\pm \mathrm{SD}$, in the same column, followed by different superscripts, are significantly different $(\mathrm{p}<0.05)$.
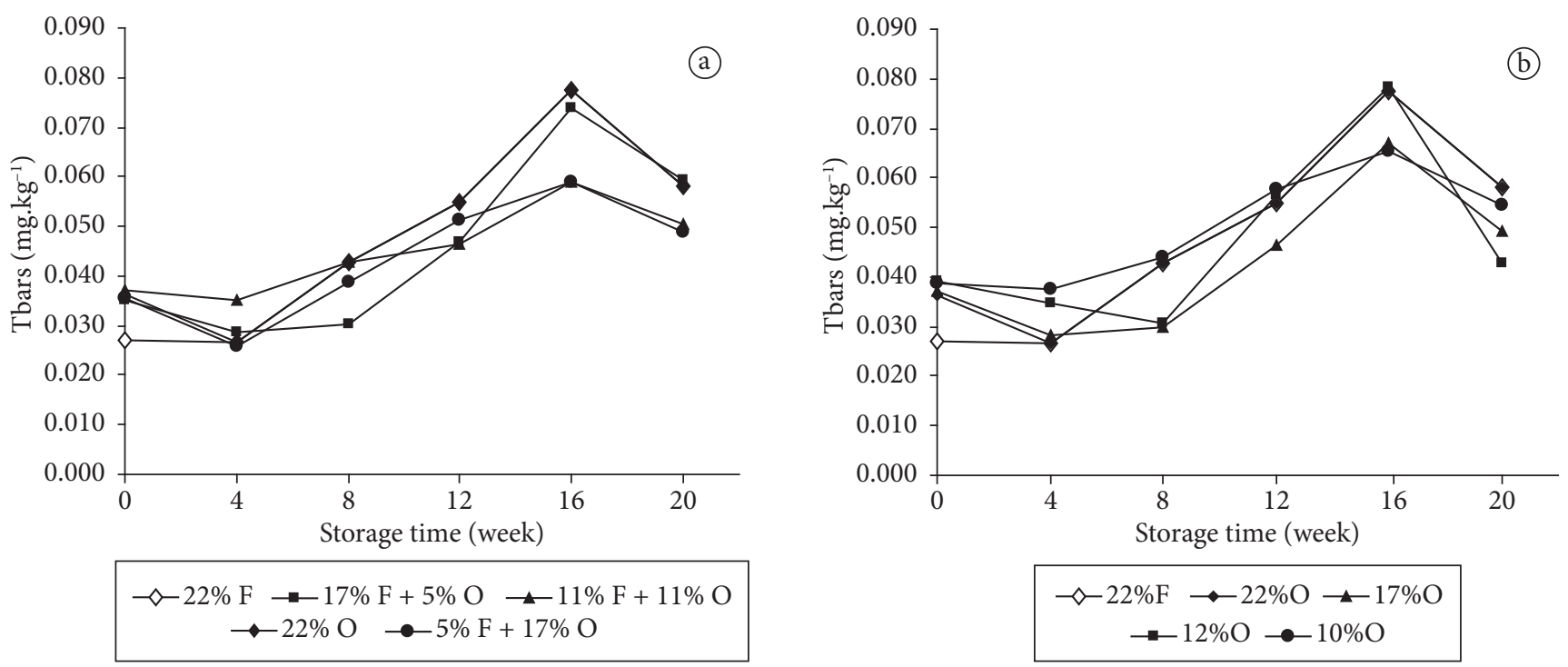

Figure 2. Changes in TBARS - thiobarbituric acid-reactive substances $(\mathrm{mg} / \mathrm{kg})$ in snacks flavored with a) mixes of partially hydrogenated oil and rapeseed oil up to $22 \%(\mathrm{~F})$; and b) snacks flavored only with rapeseed oil (O) during twenty weeks of storage. 
2006) demands further analysis. Studies examining a solution containing fat replacer, salt, and flavoring (CAPRILES; SOARES; ARÊAS, 2007) hold promising results.

\section{Conclusions}

This study showed that total and partial replacement of partially hydrogenated vegetable oil by rapeseed oil as a fixative agent for the flavors in snacks yielded products with reduced SAFA and TFA contents during the 20-week storage. All samples had similar shelf life as compared to the control snacks. These results agreed with the sensory evaluation, which showed that snacks flavored with partially hydrogenated vegetable oil and rapeseed oil were equally well accepted by consumer during the 20 weeks of storage.

\section{Acknowledgements}

The authors are grateful for the financial support provided by FAPESP (The State of São Paulo Research Foundation) and to Geni Rodrigues Sampaio, Rosa Nilda Chávez-Jauregui, José Pereira, Maria Elizabeth Machado Pinto and Silva, and Elizabeth Aparecida Ferraz da Silva Torres for their technical assistance, and to the volunteers who constituted the sensory panel.

\section{References}

ALLISON, D. B. et al. Estimated intakes of trans fatty and other fatty acids in the US population. Journal of the American Dietetic Association, v. 99, n. 2, p. 166-174, 1999.

American Oil Chemists' Society - AOCS. Trans unsaturated fatty acids by capillary column gas chromatography. AOCS Recommended Practice Ch 2a -94.USA, 1997a.

American Oil Chemists' Society - AOCS. Determination of cis and trans fatty acids in hydrogenated and refined oils and fats by capillary GLC. AOCS Official Method Ce 1f-96. USA, 1997b.

ARÊAS, J. A. G. Extrusion of Food Proteins. Critical Reviews in Food Science and Nutrition, v. 32, n. 4, p. 365-392, 1992.

ARO, A. et al. Trans fatty acids in french fries, soups, and snacks from 14 European countries: The TRANSFAIR study. Journal of Food Composition and Analysis, v. 11, n. 2, p. 170-177, 1998.

ASCHERIO, A.; WILLETT, W. Health effects of trans fatty acids. American Journal of Clinical Nutrition, v. 66, p. 1006S-1010S, 1997.

BRASIL. Agência Nacional de Vigilância Sanitária. RDC n. 360, de 23 de dezembro de 2003. Regulamento Técnico sobre Rotulagem Nutricional de Alimentos Embalados, tornando obrigatória a rotulagem nutricional. Diário Oficial da República Federativa do Brasil, Brasília, DF, 26 de dezembro de 2003.

CAPRILES, V. D.; ARÊAS, J. A. G. Desenvolvimento de "snacks" com teores reduzidos de gordura saturada e de ácidos graxos trans. Ciência e Tecnologia de Alimentos, v. 25, n. 2, p. 363-369, 2005.

CAPRILES, V. D.; SOARES, R. A. M.; ARÊAS, J. A. G. Development and assessment of acceptability and nutritional properties of a light snack. Ciência e Tecnologia de Alimentos, v. 27, n. 3, p. 562-566, 2007.

CHAIR, E. B. F. et al. Position paper on trans fatty acids. American Journal of Clinical Nutrition, v. 63, n. 5, p. 663-670, 1996.

CHIARA, V. L.; SICHIERI, R.; CARVALHO, T. D. S. F. D. Teores de ácidos graxos trans de alguns alimentos consumidos no Rio de Janeiro. Revista de Nutrição, v. 16, n. 2, p. 227-233, 2003.
ENIG, M. G. et al. Fatty Acid Composition of the Fat in Select Food Items with Emphasis on trans Components. Journal of the American Oil Chemists' Society, v. 60, n. 10, p. 1788-1795, 1983.

FRANKEL, E. N. Lipid oxidation: mechanisms, products and biological significance. Journal of the American Oil Chemists' Society, v. 61, n. 12, p. 1908-1917, 1984.

GREENE, B. E.; CUMUZE, T. H. Relationship between TBA numbers and inexperienced 'panelists' assessments of oxidized flavor in cooked beef. Journal of Food Science, v. 47, n. 1, p. 52-54, 1981.

HARTMAN, L.; LAGO, R. C. A. Rapid Preparation of fatty acid methyl esters from lipids. Laboratory Practice, v. 22, n. 6, p. 475-476, 1973.

HSIEH, R. J.; KINSELLA, J. E. Oxidation of polyunsaturated fatty acids: mechanisms, products, and inhibition with emphasis on fish. Advances in Food and Nutrition Research, v. 33, p. 233-241, 1989.

JUDD, J. T. et al. Dietary trans fatty acids: effects on plasma lipids and lipoproteins of healthy men and women. American Journal of Clinical Nutrition, v. 59, n. 4, p. 861-868, 1994.

MARMER, W. N.; MAXWELL, R. J. Dry Column Method for the Quantitative Extraction and Simultaneous Class Separation of Lipids from Muscle Tissue. Lipids, v. 16, n. 5, p. 365-371, 1981.

MARTIN, C. A. et al. Trans fatty acid content of Brazilian biscuits. Food Chemistry, v. 93, n. 3, p. 445-448, 2005.

MERCIER, C.; LINKO, P.; HARPER, J. M. Extrusion cooking. 2 ed. St. Paul, Minnesota: American Association of Cereal Chemists, 1998.

MITCHELL, J. R.; AREAS, J. A. G. Strutural in biopolymers during extrusion. In: KOKINI, J. L.; HO, C. T.; KARWE, M. V. Food Extrusion Science and Technology. New York: Marcel Dekker Inc, 1992. p. 345-360.

MUÑOZ, A. M.; CIVILLE, V. G.; CARR, B. T. Sensory evaluation in quality control. New York: Van Nostrand Reinhold, 1992.

NAWAR, W. W. Lipids. In: FENNEMA, O. R. Food Chemistry. 3 ed. New York: Marcel Dekker Inc, 1996. p. 225-320.

ROBINSON, J. E.; SINGH, R.; KAYS, S. E. Evaluation of an automated hydrolysis and extraction for quantification of total fat, lipid classes and trans in cereal products. Food Chemistry, v. 107, n. 3, p. 1144-1150, 2008.

SCHAEFER, E. J. Lipoproteins, nutrition, and heart disease. American Journal of Clinical Nutrition, v. 75, n. 2, p. 191-212, 2002.

STONE, H.; SIDEL, J. L. Sensory Evaluation Practices. London: Academic Press, 1985.

SUBBAIAH, P. V.; SUBRAMANIAN, V. S.; LIU, M. Trans unsaturated fatty acids inhibit lecithin: cholesterol acyltransferese and alter its positional specificity. Journal of Lipid Research, v. 39, n. 7, p. 1438-1447, 1998.

TAVELLA, M. et al. Trans fatty acid content of a selection of foods in Argentina. Food Chemistry, v. 69, n. 2, p. 209-213, 2000.

VYNCE, W. Direct Determination of the Thiobarbituric Acid Value in Trichloracetic Acid Extracts of Fish as a Measure of Oxidative. Fette Seifen Anstrichm, v. 72, n. 12, p. 1084-1087, 1970.

WEIHRAUCH, J. L. et al. Lipid conversion factors for calculating fatty acids contents in foods. Journal of the American Oil Chemists' Society, v. 54, n. 1, p. 36-40, 1977.

YULIANI, S. et al. Extrusion of mixtures of starch and d-limonene encapsulated with $\beta$-cyclodextrin: Flavour retention and physical properties. Food Research International, v. 39, n. 3, p. 318-331, 2006. 